\title{
Competition In The Electrical Industry: An Industrial Viewpoint\#
}

\author{
Ralph W. Greenwood
}

My earliest remembrance of a World's Fair is of New York, in 1939. The theme facility was the Trilon and Perisphere. For those of you too young (or too old) to remember, the Trilon was a three-sided obelisk similar to a half size Washington Monument while the Perisphere was a large ball not unlike the later geodesic domes of Buckminster Fuller. I can well imagine that the Trilon and Perisphere were intended to represent man's high aspirations and need for unity. A few months later the storm of World War shifted our focus and dimmed that vision.

The electric utility industry, on the other hand, was becoming increasingly strong at the time of that World's Fair, with load growing rapidly and unit costs falling. The quality of electrical supply was without equal in the world; a quality that we Americans were learning to confidently expect. A few years later nuclear power too cheap to measure seemed to hold promise of a glorious future with unlimited, inexpensive energy. The electric utility industry was a symbol of technological advance sufficient for every human need and of beneficient institutionalism. Then came OPEC and the "drop out" generation. As with the Trilon and Perisphere, again an image became tarnished by a harsh change in reality and a shift in priorities. Costs of electricity began to rise, then soared, and utilities became viewed as pernicious institutions, robbing the people of their right to the cheap, dependable electricity they had come to expect. Massive regulatory barriers were raised that drove up the cost of new electrical facilities. Our national wealth had grown to the point where, unique in human history, we could indulge ourselves in the question of the wisdom and consequences of growth. In 1974, electricity production by investor owned utilities actually dropped below that of the previous year. ${ }^{1}$ The three certainties of life had been death, taxes and $7 \%$ annual growth rate in electricity consumption. ${ }^{2}$ Then we had a sudden decline. Some forecasters saw Armageddon, others thought the $7 \%$ growth rate would return but be offset from the previous trend line by the 1974 abberation. And some felt the long term growth trend would drop as far down as perhaps $5 \%$ per year. Today, most forecasters predict long term average annual growth rates of $21 / 2$ to $3 \%,^{3-5}$ and the current rate is under one percent. ${ }^{6}$ 
The price of energy is no longer inconsequential. Rather it has become a critical factor in many business decisions. And availability of electricity has become uncertain in some areas. California had only a $6 \%$ reserve margin last summer ${ }^{7}$ and is increasingly dependent on precipitation in the Cascades to prevent brownouts or rolling blackouts. Portions of the Texas Gulf Coast may be short of electricity in a few years if current growth rates continue. Some utilities are deferring new capacity, not because of lower expected load growth but because of limitations to financial capability, thus assuring off-optimum fuel mix and bringing reserve margins low enough to stir apprehension in the hearts of knowledgeable consumers. The price and availability of electricity have become very important to many industrial customers, particularly those with energy intensive processes.

Some Union Carbide operations spend 70 percent of their direct manufacturing costs on electricity. In Louisiana and Texas alone our electricity bills for our plants run to almost $\$ 80$ million a year. And our total cost for electricity throughout the United States last year was about $\$ 420$ million. As you can appreciate, questions of adequate power supplies and nondiscriminatory pricing policies are at the heart of the competitiveness and productivity of our business.

How, then, does an intustrial customer respond to this new way of life? Certainly one of the ways is through enhanced capability for analysis of utility performance. Many of us have developed skill centers to analyze the price and availability of electricity. Each utility must be studied independently because each has its unique financial situation, fuel mix, fuel costs, growth expectations and construction programs. Our planning horizons reach from month-to-month, quarterly, annually for business budgets, five years for business planning, and twenty or more years for site selection and business analyses. The results of these analyses are used to site new plants, expand existing plants, shift production between plants and, in times of low product demand, shut down highest cost units.

Because each utility has different costs, my group at Corporate Headquarters has developed a computer program to quickly forecast costs for any specific utility. Some other energy intensive companies have similar programs for their own use, but details are usually proprietary.

Our program requires about 50 inputs. Six major energy sources are included in the model - coal, nuclear, gas, oil, hydro and purchased electricity. A seventh energy input is included for other sources such as lignite or specially contracted and priced fuels. For each of these seven parameters, values are inserted into the model for initial installed capacity and planned new capacity is megowatts; initial energy costs in Mills/KWh, rates of escalation of fuel costs in \% per year, and operating service factors. Nuclear and coal units are base loaded-the other energy sources make up the remainder of the total requirement. Other input items include base year peak load in MW, and total energy production in $\mathrm{MWh},-$-annual rate of load growth in \%, annual inflation based on GNP deflator in \%, capital expenditures by year, base year net assets employed, return on rate base for the industrial customer class, and changes in service factors for baseloaded fuels. 
The program then computes for each of 20 years expected power cost to the industrial customer class and system reserve margin.

As with most such programs, its value lies not only with the speed by which multi-year data are calculated, but also with its ability to play "whatif?" games if we wish to change a given variable. We use this feature regularly to test such changes as the effect of delays in completion of new generation capacity, increased construction expenditures, or new fuel cost values.

Although this model is relatively simplistic, we are quite satisfied with its results. Union Carbide has also developed a more comprehensive model at Oak Ridge to predict electric power costs as the gaseous diffusion plants.

Let me show you some of the variations we see in electric power costs. Figure 1 shows relative costs for purchased electricity that Union Carbide experienced in 1981. Using TVA as 100, they range from 276 in New York and 169 in California, down to 23 in the Pacific Northwest and 16 on the Niagara Frontier. Obviously, we have other criteria for plant site selection than power costs, including distribution costs, access to raw materials and labor, and taxes. But power costs can make a difference, particularly within a given region where differences between other siting factors are likely to be small. Figure 2 shows our comparison of two utilities in the Southern region. Although one is lower cost now, it becomes higher cost in the long run. Short term business decisions will favor keeping or adding load on utility A, while for new site selection, utility $\mathrm{B}$ may receive preference.

Regional trends may be of interest to you also. The values shown in Figure 3 represent a composite of forecasts based on our plants already operating in each region. Please understand that it is not an in-depth analysis of each region, but only a summary of long-term forecasts for some of our existing locations. Note that costs on the two coasts, where oil is the primary fuel, remain high and that costs on the Gulf Coast climb rapidly from their historically low values to match those on the East and West Coasts. This run-up is cause by sharply increasing gas costs and by massive expenditures for new coal and nuclear generation. Even so, the Gulf Coast fuel mix will remain off-optimum, with utilities in the region still burning gas or oil for over half of their generation past the end of this decade.

The Southern Region remains attractively priced with only a moderate rise in electric rates reflecting the mix of coal and nuclear fuels used for generation.

Again, let me caution you that considerable variation will occur even within a region. Each utility must be studied individually.

The price of electricity is heavily dependent on the price of primary fuels used for generation. Union Carbide expects the price divergence between coal and other fossil energy sources to continue to increase. We do not expect the price of coal to increase in real terms, ex. inflation, in this decade. Natural gas will be deregulated before the end of the decade and, because of conservation and ample supply, will cost about $\$ 5-\$ 6 / \mathrm{MMBTU}$ by $1990 .{ }^{14}$ We expect oil prices to rise slightly faster than inflation, but at an uneven rate responsive to cyclical discontinuities as experienced in 1973- 
74 and again in 1979. Those utilities most dependent on coal are likely to be the low cost sources of electric power for the foreseeable future.

I hope by now I've made it clear that the sophisticated industrial consumer with an energy intensive manufacturing process has numerous options when choosing a site for a new facility or for allocating production (or shut-down) between plants based on the costs incurred by the serving utility. Unfortunately, a further mechanism is in place that adds another dimension to the selection process.

In the face of rapidly escalating electricity generation costs, Public Utilities Commissions have been forced to hike rates. But because there are a great many more voter-consumers than industrial users of electricityand because, as House Speaker Tip O'Neill has been fond of pointing out, "the most important talent in a politician is the ability to count"- there have been intense political pressures to increase some users' rates more than others.

From 1972 to 1980, residential electricity rates nationwide rose an average of 115 percent. During the same period, industrial rates increased an average of 212 percent. $^{8}$ Not surprisingly, this trend has quite a bit of influence on business investment decisions.

Populist governments, in an effort to shield the residential consumer from sharply higher power costs, have shifted a disproportionate burden of costs to the commercial and industrial sectors over the past decade. We call this cross-class subsidization "rate tilt." It means that the price industry must pay for electricity is often higher than the cost to the utility of providing that electricity, and the industrial customer can be placed in further jeopardy relative to his competition. We include a factor in our rate forecase program by which the cost of electricity to the industrial consumer is adjusted to accommodate this tilt.

The real costs of rate tilts are probably far in excess of any illusory savings to residential voter-consumers. They are paid not only in increased product costs, but in jobs lost, investment not made, and economic growth foregone.

Let me put the size of this problem in perspective. A $10 \%$ tilt on our total bill would cost us over $\$ 40$ million more a year. A $10 \%$ tilt on just the nonfuel portion would cost us over $\$ 10$ million a year. In California, for example, innovative rate making is especially advanced as an art form. A few years ago our monthly electricity bill at one plant in Los Angeles went up more than $\$ 100,000$ a month. The resulting subsidy for each residential consumer amounted to an exciting 89 cents a month. ${ }^{9}$

Here in TVA territory, inexpensive hydro power is first allocated to residential consumers. None of this energy is available to industrial users. This is one of the factors that has brought TVA prices to industry higher than those of some near-by investor owned utilities. TVA's own cost-of-service study shows that hydro preference increases revenue requirements from direct served industrial customers by about $\$ 134$ million, or something approaching $9 \% .^{10}$

The California and the TVA situations are not unique. In the Philadelphia area, where a lifeline rate exists, industry pays $165 \%$ of system aver- 
age costs. Union Carbide alone pays an extra $\$ 250,000$ per year which results in a subsidy to each residential consumer of only 25 cents per year. ${ }^{11}$

Some of the mechanisms by which this rate tilt is rationalized come under the names of lifeline rates, vintage pricing, marginal costing, and capital substitution. They are already costing industrial customers millions of dollars each year, and have become a major factor in our siting and production allocation decisions.

\section{COMPARISON OF ELECTRIC RATES PAID BY COMPARABLE UNION CARBIDE CORPORATION FACILITIES}

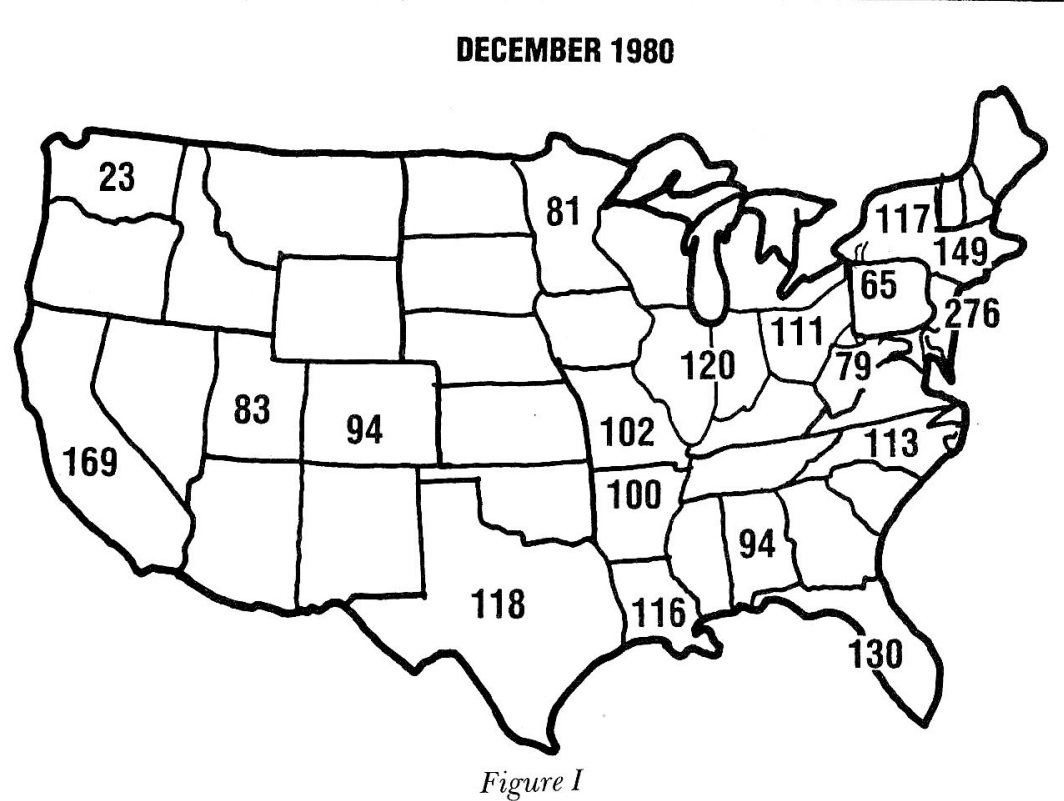

Social rate-making, subsidies of one class of user by another, departure from the cost-of-service principle in any guise is an uncertainty that industry just can't live with. It is a variable that paralyzes investment.

Another key concern in industry involves an ongoing effort to participate constructively in the broad areas of public opinion and public policy debate. Union Carbide recently sponsored a public opinion poll asking Americans how they feel about cost of service rates and electricity prices as they relate to overall economic issues. ${ }^{12}$ The survey was conducted by Cambridge Reports, Inc., during the summer of the 1981. In this survey we found that 6 out of 10 Americans believe that electricity prices should be based on cost. Eighty percent feel that electricity prices affect the cost of the final products that industry produces. 7 of 10 Americans say that industry pays attention to electricity costs in locating new plants. In fact, Americans are willing to make tradeoffs. Faced with a situation where their own electric rates would be held down at the cost of losing plants and jobs in their area, 6 out of 10 would oppose having industrial users pay higher rates. The results of this survey have been communicated to policy makers 
and Public Service Commissions throughout the country. We feel that this has gone a long way to help convince policy makers that there is no overpowering need to shelter residental consumers from increased electricity rates. On the contrary, the public believes in fair and equitable pricing and understands its importance to the economy. Now we need to succeed in convincing government officials of the value of this same principle of fairness.

In addition to social rate-making schemes, we also find rate tilts in the accounting standards of utilities and State PUC's. We generally see commissions break down costs against a "return on rate base." Although this return should theoretically be the same for each class of customer, about $80 \%$ of the time we see a higher rate of return on the industrial class than on the residential class. ${ }^{13}$ We in industry make financial decisions based on return on equity, and against this yardstick the disparity between industrial and residential rates is even greater. In a recently concluded Louisiana Power and Light case, we found that residential customers were served on a $4.3 \%$ return on equity, while industrial customers were served on a 27.9\% return. Pacific Gas and Electric in California has gone even further. Residential returns are on a .6\% basis while industrial returns yield $46.7 \%$ on equity invested by PG\&E. It would appear that one customer's return on rate base is another customer's subsidy. Let me assure you: industry is willing to pay its full and fair share of the electricity it consumes. But we object to the manipulation of electricity rates as a social mechanism to relieve other consumers of the need to pay their full, fair share.

If the electric utility industry is to break out of its present stalemate-a move in which all industrial energy users have a vital stake-I think three fundamental changes are going to have to be brought about.

The first is that State Public Utility Commissions have to reconcile themselves to allowing utilities the potential to earn a rate of return sufficient to enable them to compete for financing in money markets. And it is going to have to be a rate of return based on true cost-of-service to all classes of customers. Utility balance sheets must be unburdened by subsidies and social welfare programs.

Second, the maze of regulatory obstacles to constructing and operating a power plant have to be untangled, be they procedural, environmental or jurisdictional. Equally important, the promiscuous access to the judicial process that enables special interest groups to defeat a project simply by stalling it to death has to be dealt with. At least federal agencies have cut back the funds available to pay for the legal costs of special interest groups who want to challenge any energy project on environmental grounds, as the EPA used to do. Perhaps it is time to move on to curb the use of the courts for manipulation in other ways.

Third, we-and by we I mean utilities and their major industrial consumers - are going to have to get behind efforts to develop innovative ways to generate and use power more efficiently.

Cogeneration of electricity by industry itself is perhaps the most readily accessible and least understood of these. Union Carbide has been a co- 




Figure II

generator for more than 60 years. We recently negotiated a contract with Texas-New Mexico Power involving our chemical plant in Texas City, Texas that allows us to sell up to 25 megawatts of power to the utility.

Cogeneration depends on having a nearby beneficial use for the heat produced. Steam can be transported economically only a few miles. And as we succeed in conserving energy in our processes, the need for cogenerated heat input actually decreases. It's ironic but true that the better job we do in energy conservation, the fewer opportunities we have for cogeneration. And of course, the scale of investment in cogeneration must be economically sound in terms of the value of surplus energy it yields.

In the two industries where the special conditions favorable to cogeneration occur-paper and petrochemicals-it is nothing new. And where these conditions don't tend to occur naturally, cogeneration remains unlikely.

The Public Utility Regulatory Policy Act of 1978 does help to remove some barriers to cogeneration that could lead to more of the kind of arrangements that Carbide has made with Texas-New Mexico Power. It removes to a large degree that fear on the part of an industrial cogenerator that it will be classified as a utility, and it pressures the utilities to buy power from industrial cogenerators-something many used to resist. 
Attractive economies can also be obtained, in special circumstances, if the industrial customer is allowed to transfer power between its locations, a system the utilities call "wheeling". It's time for industry to be given access to the grid, with appropriate controls and compensation to the utility. Basic principles still apply; other ratepayers and the utility owners must not be hurt, and access in no way implies deregulation.

Let me give you some examples. At one time we had two major plants in a single state but served from different utilities. One had self generation with about $20 \mathrm{MW}$ excess capacity, the other purchased over $150 \mathrm{MW}$ and had no self-generation. Load at this second plant was curtailed because of short-term generation limitatons being experienced by the utility. Operations were restricted and workers were sent home. Why not use the excess capacity of the first plant to maintain operations at the second? In another instance, an industrial customer currently desires to convert an existing gasfired self generation plant to coal. He would like to take advantage of economies of scale to build a larger coal-fired plant and move the excess power to his other plant in the same state. Local utility rates are much higher than the cost of this coal-fired capacity. Why not allow the customer to build an economic facility and transmit the excess power to his other location for a reasonable transmission feee?

We have to plan for the future, not just hope for it. And I suggest that sound planning involves a commitment to three basic strategies:

First, we in industry should be actively and vocally involved in the "great rate debate" on electricity pricing in all four branches of governmentLegislative, Executive, Judicial and Regulatory. Never mind that the Constitution only names three branches of government. We now have four. Some cynics even add a fifth branch-the press.

Second, we must see to it that one of the first considerations in planning for a new or expanded facility is a careful study of a utility's ability to meet our needs out into the future, from both a cost and supply reliability standpoint. At the same time, we should carefully scrutinize the track record of a state regulatory agency to determine whether it is prone to make decisions based primarily on fact or primarily on political considerations.

Third, we have to look at the basic energy source to be used and compare its cost and availability to sources in other areas. At Union Carbide, we like to look at coal, and we like to look at states where utility systems are sourcing their plants with coal.

In summary, then, competition does exist between utilities. Many industrial consumers have a significant degree of freedom in how they respond to the price of electricity. Many of us have established skill centers to evaluate present and future prices for purchased electricity and we are continuing to improve those skills. The price of electricity to industrial consumers does have an impact on where we do business-or do not do business-and how many jobs result.

Those of us interested in electric power for our industries have a demanding job ahead of us. We have to keep a constant vigil over all the state commission activities to insure that rates are based on cost and that 


\section{PURCHASED ELECTRIC POWER (MILLS/kWh)}

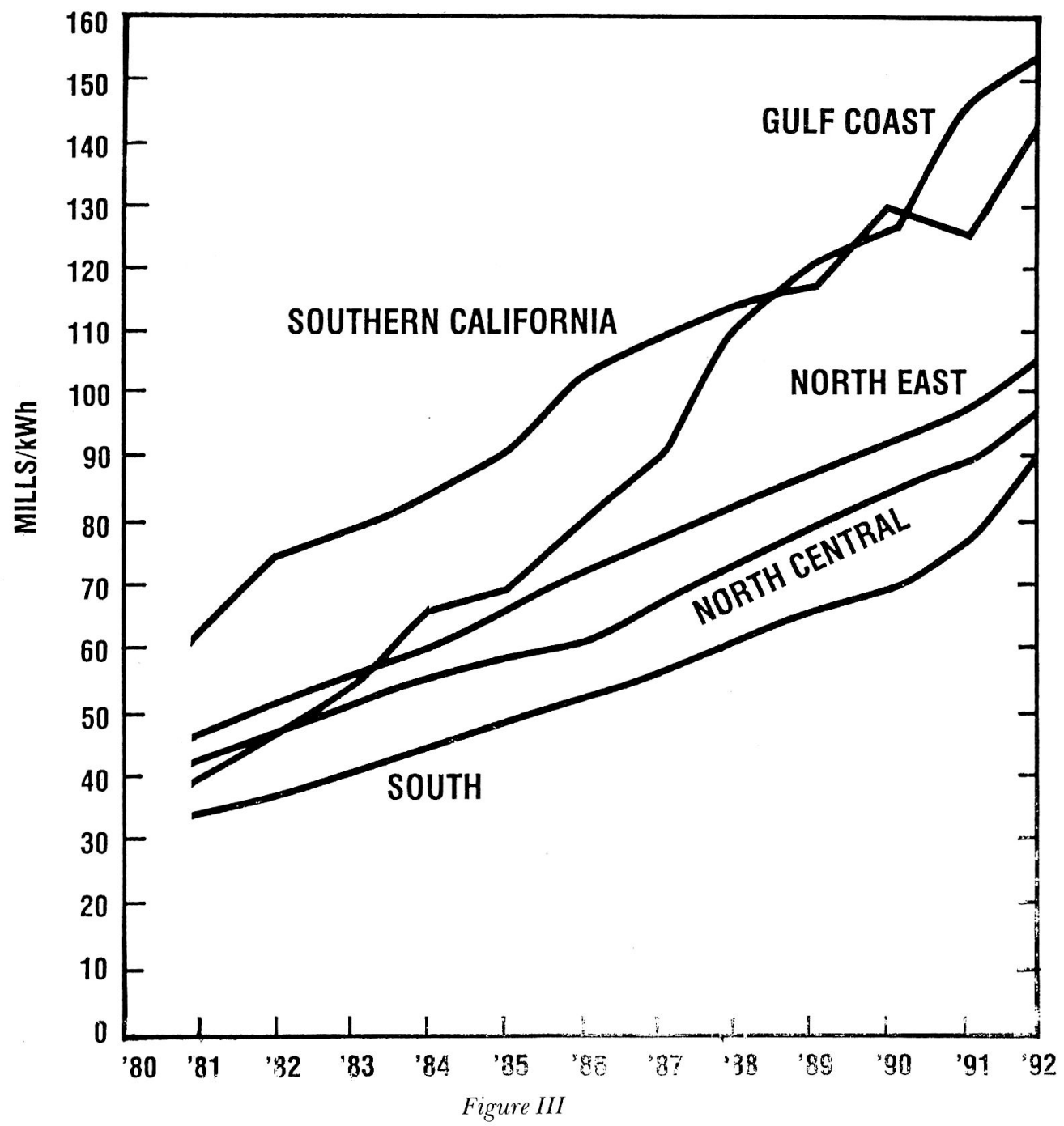

we are paying a fair and equitable price for electricity.

We must forecast accurately the pricing of electricity by utilities in places where we have plants or are considering building new plants. This assessment must include not only the technical considerations of load growth, fuel price and mix, and capital requirements. It must also consider the costs of any political ratemaking biased against industry. I'm convinced that industrial consumers must be a part of the solution and a part of the debate that goes on to improve energy policy overall. The cost of staying home may be the cost that forecloses our economic future. 


\section{FOOTNOTES}

'Energy Information Administration, as reported by Edison Electric Institute, "Electric Utility Industry Statistics", 26th Ed., 1980, p. 6.

${ }^{2}$ Op. Cit. 1960-1973 average compound rate of increase was $7.18 \%$

${ }^{3}$ Energy Information Agency, "Impacts of Financial Constraints on the Electric Utility Industry" DOE/EIA0311, December 1981.

${ }^{4}$ Exxon Energy Outlook, 1980-2000: p. 11 (2.5\%).

${ }^{5}$ National Electric Reliability Council (1982); NERC Forecasts $3.0 \%$ annual growth in peak demand between 1982 and 1991.

${ }^{6}$ Edison Electric Institute, "Electric Output" (Weekly) 52 weeks ending May 1, 1982: 0.3\%.

${ }^{7}$ Pacific Gas and Electric, Form 10K for Fiscal 1981, p. 5 .

8"Statistical Yearbook of the Electric Utility Industry", Edison Electric Institute Vol. 48; Nov. 1981; Based on Table 62, p. 63.
${ }^{9}$ Los Angeles Dept. of Water and Power (Residential), and Union Carbide.

10"Allocation of Low-Cost Power Benefits and Assignments of Benefits in Rate Design", TVA; May, 1982, p. 2.

${ }^{11}$ Union Carbide internal studies.

12“"Electricity Pricing: Choices for the 80's-American Attitudes on Electricity Pricing and Economic Growth" survey conducted by Cambridge Reports, Inc. for Union Carbide Corporation, 1981.

${ }^{13}$ Electricity Consumers Resource Council Profiles in Electricity Issues No. 6- "Cost of Service Survey", May, 1982. Survey covers 701 studies, 100 utilities in 40 states. Industrial rate of return exceeds residential rate of return in $84 \%$ of the studies.

${ }^{14}$ Updated August, 1984. 